\title{
The psychology and neuroscience of partisanship
}

\author{
Elizabeth Harris ${ }^{1}$ \\ Philip Pärnamets ${ }^{1,2}$ \\ Anni Sternisko ${ }^{1}$ \\ Claire Robertson ${ }^{1}$ \\ Jay J. Van Bavel ${ }^{1,3}$ \\ ${ }^{1}$ Department of Psychology \\ New York University \\ ${ }^{2}$ Division of Psychology, Department of Clinical Neuroscience, \\ Karolinska Institutet \\ ${ }^{3}$ Center for Neural Science \\ New York University
}




\section{The psychology and neuroscience of partisanship}

Citizens across the globe are becoming increasingly divided by their political identity (Kevins \& Soroka, 2018; Pew Research Center, 2014; Zimerman \& Pinheiro, 2020). In the United States, partisan differences in identity and values continue to widen (Kozlowski \& Murphy, 2019) even as other identity and value differences (e.g., based on religion, race, education, etc.) remain relatively stable (Pew Research Center, 2017). Over the past few decades, this chasm between political parties has grown in the U.S. among both politicians and the general public (Desilver, 2013), and similar patterns have been observed in several other nations, including New Zealand, Canada and Switzerland (Boxell, Gentzkow, \& Shapiro, 2020). These partisan differences have infused many domains of social life with political conflict. For instance, $72 \%$ of Democrats would not, or "probably would not", consider being in a relationship with someone who voted for U.S President Donald Trump (Brown, 2020) and would prefer to have a roommate from the same political party as themselves (Shafranek, 2019). These patterns reveal that polarization is occurring not only in terms of policy beliefs, but also in terms of our feelings about the other party--known as affective polarization (Boxell, Gentzkow \& Shapiro, 2020; Iyengar, Lelkes, Levendusky, Malhotra \& Westwood, 2019; Pew Research Center, 2014; see Chapter 13).

Why have citizens become increasingly polarized? The answer is that there is increasing identification with political parties - a process known as partisanship (Mason, 2018). This chapter will focus on the role that social identity plays in contemporary politics (Greene, 2002). These party identities influence political preferences, such that partisans are more likely to agree with policies that were endorsed by their political party, regardless of the policy content, and, in some cases, their own ideological beliefs (Cohen, 2003; Samuels \& Zucco Jr, 2014). There are many social and structural factors that are related to partisanship, including polarization (Lupu, 2015), intergroup threat (e.g., Craig \& Richeson, 2014), and media exposure (Tucker et al., 2018; Barberá, 2015). Our chapter will focus on the psychology and neuroscience of partisanship within these broader socio-political contexts. This will help reveal the roots of partisanship across political contexts.

\section{The psychological roots of partisanship}

According to Social Identity Theory (Tajfel \& Turner, 1979), people are prone to form social groups (i.e., a collection of individuals who categorize themselves as similar to each other, but different from others, on some dimension) and develop a feeling of attachment towards these groups. Social identification often revolves around meaningful social categories (e.g., racial groups, religious groups), but can also be based on arbitrary social categorizations (termed "minimal groups"). For instance, people randomly classified as an "underestimator" or "overestimator" based on a bogus performance feedback were more likely to allocate more resources to an anonymous ingroup member than an anonymous outgroup member (Tajfel, 1970; Tajfel, Billig, Bundy, \& Flament, 1971) and this pattern of ingroup bias is mirrored in brain activity upon seeing fellow ingroup members (Van Bavel, Packer \& Cunningham, 2008). There is growing evidence that members of political groups harbor many of the tendencies inherent in social identity (Iyengar \& Krupenkin, 2018; Mason, 2018). In the domain of politics, these basic tendencies to identify with groups are amplified by competition for scarce resources (Sherif et al., 1954), different moral values (Graham, Haidt \& Nosek, 2009; see Chapter 29), and intersections with other identities, such as national identity (Huddy, 2001), religion and race (Pew Research Center, 2020). As such, social identity is a core feature of partisanship. 
Recent research suggests that political group identity is represented similarly in the brain to more arbitrary group identities. For instance, Cikara and colleagues used multivoxel pattern analysis in functional Magnetic Resonance Imagining (fMRI) to determine if partisan identities elicit similar patterns of activation in the brain to arbitrary group identities (Cikara, Van Bavel, Ingbretsen \& Lau, 2017). The researchers looked at brain activation as participants saw members of an arbitrary ingroup (i.e., random teams they formed at the beginning of the experiment), as well as people who shared their political affiliations. When they examined the pattern of brain activation associated with thinking about an arbitrary group identity, they found that a similar pattern of brain activation was related to thinking about one's real-world political identity. This was driven by the recognition of ingroup members (as opposed to outgroup members) mirroring classic research on ingroup bias (Brewer, 1979, 1999). These findings suggest that arbitrary groups are represented in the brain similarly to partisan groups - providing the neural foundations of partisanship.

Partisanship motivates intergroup discrimination. For instance, a recent set of experiments found that avoidance and discrimination of partisan outgroups took precedence over personal benefits (Lelkes \& Westwood, 2017). In one experiment, US partisans who identified as Republican or Democrat chose to work with a less competent partner who identified as Independent over a more competent partner of the opposite party, even though the task was entirely unrelated to politics (i.e., solving puzzles). In another experiment, partisans were willing to forgo financial gain if doing so would harm their political outgroup (McConnell, Margalit, Malhotra, \& Levendusky, 2018). Specifically, roughly $75 \%$ of partisans chose a $\$ 3$ bonus over a $\$ 6$ bonus that was yoked to an additional donation to a rival party (vs. an impartial organization). The effect size of partisanship on economic decisions was comparable to the effect of religious identity. These results suggest that partisanship mirrors other important social identities such that people are motivated to enhance the status of their political ingroup and decrease that of their political outgroup--even when it comes at their own expense.

Partisanship also influences judgments and biases punishments of moral transgressions analogous to other group identities. For instance, people punish ingroup members less harshly than outgroup members for non-cooperative behavior (Anwar, Bayer \& Hjalmarsson, 2012; Chen \& Li, 2009; Goette, Huffman, \& Meier, 2012; Yudkin, Rothmund, Twardawski, Thalla \& Van Bavel, 2016). This same dynamic plays out in political contexts. For instance, Spaniards rated a corruption case as more serious when it implicated a politician from the opposing party than when it implicated a politician from their own party (Anduiza, Gallego, \& Muñoz, 2013). Further, Ugandans were less likely to blame the government for poor services (e.g., health care) in their local community when they were supporters (vs. opponents) of the then incumbent president (Carlson, 2015). In other words, political identity influences intergroup behavior similar to other social identities around the world.

\section{The Biological Roots of Partisanship}

In the last few decades, there has been a surge of interest in the effects of group membership on cognitive and biological processes with the goal of better understanding how these processes, in turn, contribute to parochialism, prejudice, and intergroup conflict (see Cikara \& Van Bavel, 2014, for a review). Although the majority of this work has ignored partisanship per se, there are some important exceptions. In this section, we review recent work related to the biological foundations of partisanship. 
Recent work suggests that physiological and psychological characteristics (including personality traits) are heritable, stable, and difficult to change, and so they must shape political dispositions, rather than the other way around (Hibbing, Smith \& Alford, 2013; Jost, Hennes \& Lavine, 2013). As such, the relationship between political attitudes and personality traits appears to be a function of an innate underlying genetic disposition (see Verhulst, Eaves, \& Hatemi, 2011). For example, twin studies have found that genetic influences account for roughly $40 \%$ of the variation in political ideologies (Hatemi et al., 2014). These biological differences between people with different political views have also been observed in terms of gray matter volume differences in various brain structures (see Chawke \& Kanai, 2016; Nam, Jost, \& Van Bavel, 2018. This overarching pattern of results has led some to conclude, quite erroneously, that social and political outcomes (such as racism, political orientation, and partisanship) are "hard-wired" (see Jost, Noorbaloochi, \& Van Bavel, 2014). We think this conclusion is premature and misunderstands the relationship between the underlying biology and its interaction with the social and cultural context.

It is more accurate to say that social factors may shape the link between these ideological orientations and partisanship. Because identification with a political party is a voluntary process, people tend to be attracted to political parties that align with their ideology. Indeed, the relationship between political ideology and party identification is very high. However, this link can change over time. For instance, the correlation between conservative ideology in the US and identification with the right-wing Republican Party has grown from a moderate correlation to a very strong one in the past few years (see Klein, 2020; Van Bavel \& Pereira, 2018). The alignment with political ideology and partisan identity is likely to be especially high during periods of polarization or when political systems are dominated by two competing groups because these factors can heighten partisan motives effective in creating a sense of 'us' versus 'them' (Hartstone \& Augoustinos, 1995; Van Bavel \& Pereira, 2018). It can also amplify partisan conflict since it becomes harder to find grounds for compromise when the members of opposing political parties possess different policy preferences and dispositions toward the world.

Another issue is that the tendency to identify with a group--or harbor ingroup bias--is itself shaped by biology (see Chapter 7). For instance, research on twins suggests that genetics partially determine the tendency to affiliate with arbitrary groups and exist alongside essentialist tendencies that evolved to process salient cues, such as shared beliefs and ancestry (Lewis \& Bates, 2010). Moreover, there appears to be independent genetic effects accounting for individual differences in ingroup love (i.e., patriotism) and outgroup derogation (i.e., prejudice; Lewis et al., 2013). Thus, while forging coalitions and building group identities appears to be universal — since it has been observed in cultures studied around the world (Brown, 1991) — not everyone is equally group-ish. In short, some people might be more inclined to adopt partisan identities or engage in hyper-partisan beliefs.

In political domains, ingroup favoritism may be intensified by a history of conflict and competition for limited resources (i.e., votes), differences in values and ideology, and the stereotypical exaggeration of actual differences (known as false polarization; Wilson, Parker \& Feinberg, 2020). As a result, it is hardly surprising that partisan affiliations influence how people evaluate political candidates and policies. In one of the first studies of neural correlates of political preferences, researchers examined implicit preferences of participants in relation to well-known Democratic and Republican politicians (Knutson et al., 2006). The researchers found a negative correlation between the participants' strength of partisan affiliation and their activation in the lateral prefrontal cortex (LPFC). The LPFC may serve to downregulate 
automatic association and valuations driven by activation in areas such as the ventral medial prefrontal cortex (vmPFC). Activation in the vmPFC, a part of the brain's core valuation system (Bartra, McGuire \& Kable, 2013), correlated with participants valuations of politicians in this study (Knutson et al., 2006). Other neuroimaging studies have attempted to identify an overlap between the brain regions implicated in self-referential processing, such as the ventral medial prefrontal cortex (vmPFC; Kelley et al., 2002; Mitchell et al, 2006), and mentalizing about political ingroup members. A link between these areas could suggest overlap in processing of the self and of political ingroup members. These studies have sparked a larger body of research designed to understand the neuroscience of intergroup relations and partisanship (see Jost et al., 2014).

To better understand these neural component processes, we recently outlined several brain regions implicated in the processing of partisan information (Van Bavel \& Pereira, 2018). When partisans encounter new or ambiguous information in the world, this information is often interpreted through the lens of that particularly social identity (see Xiao, Coppin, \& Van Bavel, 2016). We speculated that the orbitofrontal cortex (OFC) may be responsible for computing the value of competing goals: identity goals versus accuracy goals. This region allows highly identified partisans to prioritize the outcomes of ingroup members and engage in cognition and action consistent with their identity goals. Such identity goals include the desire to belong in the group, obtain social status, and feel morally superior. The OFC has functional connections with other brain regions involved in reasoning (dorsolateral prefrontal cortex), memory (hippocampus), implicit evaluation (amygdala), and even perception (visual cortex; see Figure 1) - allowing partisan values to influence a variety of cognitive systems. Evidence from social and cognitive neuroscience suggests that these brain regions engage in distinct computations while generating evaluations. Thus, the impacts of partisanship may be dissociated at the neural level and underlie different forms of partisan bias. 


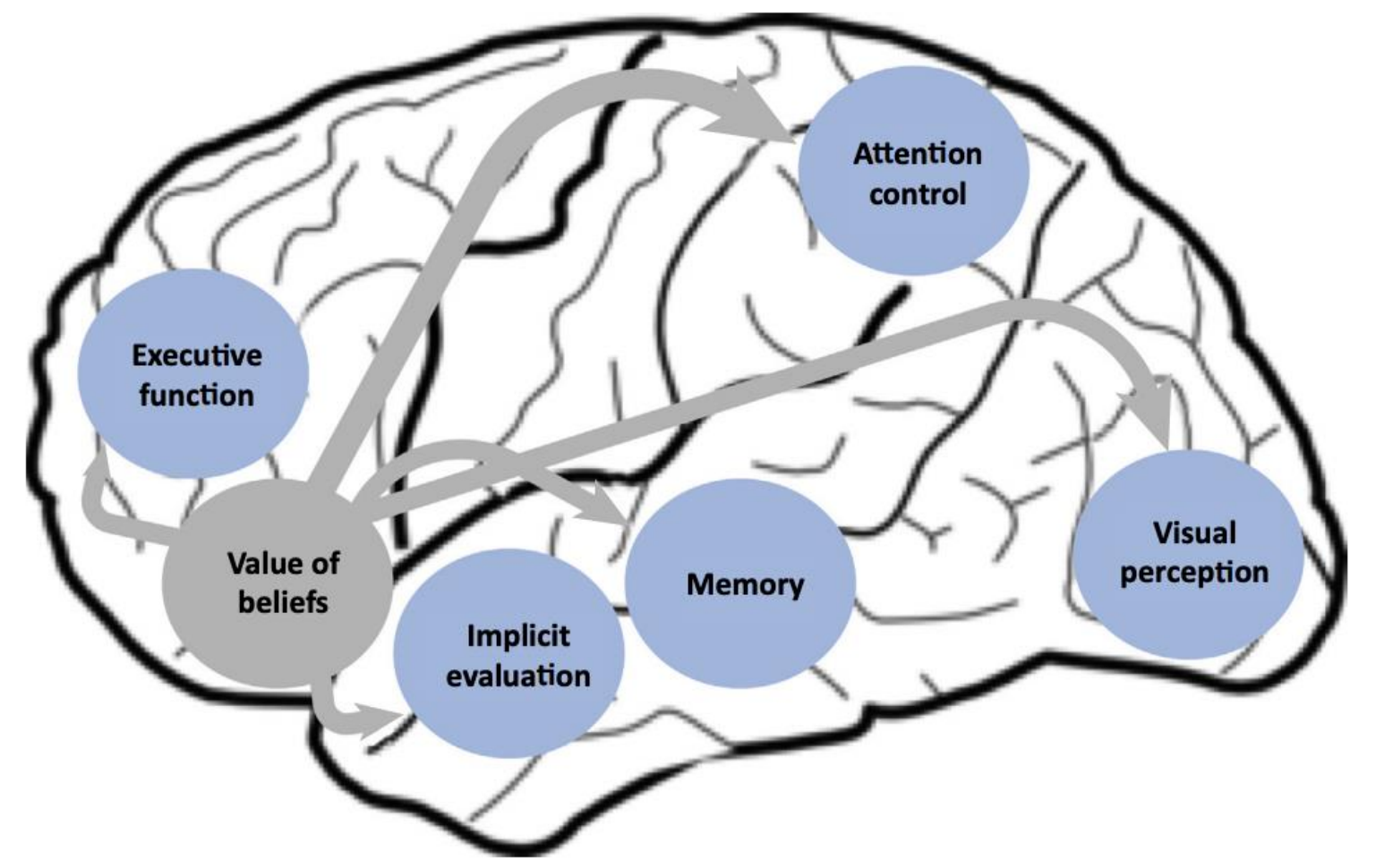

Trends in Cognitive Sciences

Figure 2. The Value of Beliefs Shapes Different Cognitive Processes. The identity-based model of belief assumes that partisan identities determine the value of different beliefs and can therefore distort belief at different states of cognitive processing, including executive function, attention control, memory, implicit evaluation (corresponding to the amygdala/ hippocampus, not visible from this perspective), and visual perception. This cartoon roughly illustrates that these cognitive processes have dissociable neural substrates and can be treated as being functionally distinct. In practice, the functional relationships between different cognitive processes are often bidirectional.

Understanding these neural processes may be useful to promote an understanding for the complexity of the processes interacting to produce partisan cognition and beliefs (e.g. Figure 1) For instance, if an individual is engaged in motivated reasoning, then presenting them with additional factual information is unlikely to be of much value - they will either find a way to dismiss the source or counter-argue against the evidence. Many strategies are unlikely to be effective if the source of the bias is unconscious because these processes unfold automatically, without motivation or cognitive capacity. Likewise, correcting distortions in memory will require deep and repeated engagement with the political content or effective cues for retrieval. Understanding the contribution of core valuation systems, memory and systems governing identity can help researchers to design interventions that take into account the processes involved, and therefore may be more effective. However, research into the neuroscience of partisanship and identity is in its infancy and in the current state of knowledge, policy-makers and the public should remain skeptical of neurally-motivated attempts at reprogramming political or partisan beliefs.

\section{Partisanship affects numerous beliefs, judgements and behaviors}


Many studies investigate the effect of partisanship on various outcomes. In the current chapter, we focus on the effects of partisanship on beliefs generally, belief in misinformation, belief in conspiracy theories and voting behavior. The debates on the effects of partisanship on beliefs and reasoning have largely focused on several related questions: (1) How does partisanship affect belief change in light of contradictory evidence? (2) Are informationprocessing biases similar across the ideological spectrum or particularly associated with one side of the political aisle? (3) Do partisan identities influence of the belief and dissemination of misinformation? (4) Does partisanship influence substantive political behavior?

Belief perseverance and belief updating. When we process political information, people are influenced not only by the evidence itself, but also by our goals, including self, group and system-serving goals (Jost, Hennes \& Lavine, 2013; Van Bavel \& Pereira, 2018). Indeed, extensive research suggests that individuals are motivated to process politically relevant information in a biased manner (e.g., Kahan, Peters, Dawson \& Slovic, 2017; Meffert, Chung, Joiner, Waks \& Garst, 2006). Motivational models propose that when information is group identity-congruent yet untrue, our social identity motives conflict with our accuracy motivation. Whether we believe the information or not depends on the weights we give to these motivations which change across different contexts. Politically biased motivated cognition extends well beyond reasoning (Van Bavel \& Periera, 2018) and does not appear to be unique to the United States, with similar biases appearing in Brazil (Samuels \& Zucco Jr, 2014) and Uganda (Carlson, 2016). Therefore, we believe this element of political cognition is nearly universal and is activated by the features of the local political environment (e.g., polarization, election proximity, media coverage, discourse from political elites, etc).

When faced with evidence that contradicts one's beliefs, practical rationality and social norms, we expect a person to update or change the credence of those beliefs. Therefore, findings that people maintain beliefs that have been discredited as complete falsehoods has been studied by psychologists for over 50 years (e.g., Festinger, Riecken, \& Schachter, 1956; McGuire, 1964; Ross, Lepper \& Hubbard, 1975). Resistance to disconfirming evidence also extends to beliefs driven by partisan identity. For example, using large representative samples of voters, studies. have found that people continued to believe statements that aligned with their partisan identity, despite those statements being labelled as false (Bullock, 2007). These partisan biases have now been observed in a wide variety of contexts and tasks with robust evidence of motivated reasoning across the political spectrum (Ditto et al., 2018; Mason, 2018; see also Chapter 16).

Belief perseverance - the failure to update in light of new evidence - is typically also interpreted in terms of a motivated cognition framework (Kunda, 1990; Taber \& Lodge, 2006; Taber, Lodge \& Glathar, 2001). Accordingly, cognition is affected by the agent's current motivations or goals. While many people have the goal to be accurate, cognitive scientists have argued that one of the most important goals for people is the communicative goal to convince others of one's position (Mercier \& Sperber, 2011). Communicative goals can be manipulated to strengthen accuracy. For example, telling people they will publicly have to discuss their judgments leads them to process information more fairly (Tetlock, 1985). Importantly, goal selection is not only determined by external means, but also by goals associated with one's identity, which is a likely route for how partisanship affects one's beliefs and reasoning processes (Van Bavel \& Pereira, 2018). These group identity-based goals motivate individuals to see their own party in a favorable light, which may weaken accuracy goals if the truth does not align with one's partisan identity or if their identity group does not embrace the norms of 
accuracy and objectivity (Van Bavel et al., 2020. This can be seen in how partisanship shapes beliefs about the economy following a shift in political power, whereby people rapidly change their beliefs to bolster their identity (Gerber \& Huber, 2010). However, it is important to distinguish between partisan cheerleading and actual differences in held beliefs. For example, incentivizing people to respond accurately or giving them the option "don't know" to politically charged survey items (with a factual basis) largely erases partisan gaps in responses to many politicized questions (Bullock, Gerber, Hill \& Huber, 2015). This is why more objective measures of behavior are necessary to determine if survey measures accurately reflect beliefs (e.g., Gollwitzer, Martel, Brady, Parnamets, Freedman, Knowles, \& Van Bavel, 2020).

Other researchers approach the study of politically relevant information processing from a Bayesian updating framework (Ripberger et al., 2017; Coppock, 2016). The Bayesian framework posits that when agents come across a new piece of information, they use their prior knowledge (i.e., their "priors") to create a probability distribution of its likelihood of being true, which results in an updated belief (i.e., the "posteriors"; McNamara \& Houston, 1980). For example, when a liberal is more likely to believe that the conservative party's leader committed a crime than the liberal party's leader, this is not necessarily a biased response but a rational conclusion by the individual given their prior knowledge that they bring into the situation. This could, for example, include more awareness of transgressions committed by conservatives than by liberals, causing them to infer that the former is more likely (see Tappin, Pennycook \& Rand, 2020).

The Bayesian approach is often contrasted with other forms of politically motivated reasoning and might account for what otherwise appears to be motivated reasoning. It is sometimes claimed that Bayesian reasoners, by necessity, must converge to the same opinion and exhibit symmetrical updating - i.e. treat information from partisan sources equally (see, for example, Bartels, 2002). However, this conception is incorrect and depends on how beliefs are modeled. More sophisticated models which assume that people also estimate the variance (certainty) of information they observe, and have priors about these, can achieve belief polarization to the same observables under perfectly 'rational' Bayesian updating (Gerber \& Green, 1998; Bullock, 2009). That said, we believe it is important to take accuracy and consistency into account when discussing "bias" and rationality (Baron \& Jost, 2019). If partisan "bias" leads people to generate more accurate beliefs, then it is hard to call their judgement irrational. And if priors lead people to generate less accurate beliefs, then it is hard to call their judgement rational.

If one's priors are affected by partisan cues and the reasoner's identities, then the Bayesian approach may provide a powerful formalism for understanding and modeling the many psychological effects of partisanship. For example, there is an effect referred to as selective partisan exposure. Research suggests that partisans are more inclined to both select partisan consistent information to read and read such information more deeply (e.g., Graf \& Aday, 2008). Similarly, in the US, there is a marked divide in the news sources that Democrats and Republicans choose to expose themselves to (Jurkowitz, Mitchell, Shearer \& Walker, 2020). Selective exposure is one likely cause of differing priors, fueling "rational" asymmetric updating. Attention is thought to play a large role in how humans and animals explore and decide (Gottlieb, 2018) and rational attention may explain partisan echo chambers and similar phenomena (Che \& Mierendorff, 2019; see also Chapter 33). Researchers have also applied a Bayesian updating framework to multiple processes involving political information, such as 
perception of climate-related events (Ripberger et al., 2017), political persuasion (Coppock, 2016) and the formation of partisan attitudes (Gerber \& Green, 1998).

Partisan symmetry debate. A large part of the scholarly work on partisan biases is about whether they are observed symmetrically or asymmetrically (i.e., are they equally observed on the political left and right?) This question is largely explored in a US political context (e.g., see Chapter 42), bringing with it two consequences. First, due to the US two-party system, partisanship and ideology are often conflated. Second, the debate of whether partisanship affects cognition symmetrically or asymmetrically is often framed in terms of whether Republicans (conservatives) are more biased than Democrats (liberals), or if bias is bipartisan (affects Republicans and Democrats equally).

One highly influential hypothesis is that different self-identified partisan and ideological affinities are associated with varying degrees of bias and cognitive inflexibility. Results in this literature are highly mixed and likely dependent on the stimuli under consideration (see Harris \& Van Bavel, 2020). Evidence for asymmetry has, however, been demonstrated in a wide range of apolitical contexts, where it is easier to make broader generalizations about asymmetry. For example, conservative participants explored novel stimuli less, likely due to emphasizing negative events more during the learning phase (Shook \& Fazio, 2009). Similarly, another study showed that Republican leaning participants anchored their political belief updating more on prior irrelevant information compared to Democratic leaning participants (Hornsby \& Love, 2020). A large meta-analysis found that political conservatism was associated with, amongst other things, higher dogmatism, lower uncertainty tolerance, lower openness to new experience (Jost, Glaser, Kruglanski \& Sulloway, 2003). Other work has found biases associated with liberalism, such as illusions of uniqueness (Stern, West, \& Schmitt, 2014). These suggest that there are robust, measurable differences in cognitive style between liberals and conservatives.

Other work has demonstrated a symmetry in the cognitive effects of partisanship and political extremism (see Chapter 16). Results from a composite measure of political beliefs, including voting behavior and ideology, revealed that political extremism is associated with degraded metacognition (Rollwage, Dolan \& Fleming, 2018), lower cognitive flexibility (Zmigrod, Rentfrow \& Robbins, 2019), belief superiority, and dogmatism (Harris \& Van Bavel, 2020; Toner et al., 2013). When participants receive false-feedback about their own stated political attitudes, they did not correct the false feedback at different rates due to their degree of partisan involvement in both Swedish (Strandberg et al., 2018) and US samples (Strandberg et al., 2020). Similarly, a recent meta-analysis found that Democrats and Republicans were both more inclined to evaluate information more favorably when it aligns with their partisan identity (Ditto et al., 2018). Taken together, we believe there is good evidence for both symmetry and asymmetry in biased political cognition in different domains. As such, tuture theorizing should move beyond the symmetry vs. asymmetry debate, and focus on where and why each pattern is likely to be observed.

Misinformation. In 2017, "fake news" was named the Collins Dictionary word of the year (Hunt, 2017). This dubious honor reflects the large impact fake news has had on economic, political and social behavior in recent years. Fake news is false information distributed as if it is real news, and it reflects one form of misinformation that is common in the political domain (see Van Bavel, Harris, Pernamets, Rathje, Doell, \& Tucker, 2020 for a review) The influence of misinformation poses an existential threat to democracy because it confuses voters, fosters social conflict, undercuts trust in important institutions, and increases polarization. Understanding what drives belief in misinformation is important, especially in a world where political polarization is 
becoming more and more extreme (Pew Research Center, 2017). There is the concerning potential for a cycle in which political division feeds belief in partisan misinformation, and belief in partisan misinformation increases political division (as some analysts suggest is happening now; Sarlin, 2018). This vicious cycle activates the basic human capacity for partisanship and can foster social conflict.

This cycle now operates in a world where over 3 billion people have social media accounts and social media has become the main source of news for many (e.g., for approximately two thirds of Americans; Shearer \& Gottfried, 2017). This technological revolution makes it easier for partisans to create and distribute fake news, propaganda, conspiracy theories, and other forms of misinformation. Specifically, political fake news has become increasingly frequent, especially leading up to large political events. In fact, people engaged with (e.g., "liked", "shared", etc.) fake news more than real news in the few months leading up to the 2016 US election (Silverman, 2016). Similarly, a recent analysis of rumors spread by over 3 million people online found that misinformation spread significantly more than truth - and the power of fake news was greatest for political content (Vosoughi, Roy \& Aral, 2018). In recent years, the academic investigation of misinformation has grown rapidly. This body of work explores many potential factors that influence fake news belief, ranging from repetition of the fake news story (Fazio, Rand \& Pennycook, 2019) to reduced analytic thinking (Bronstein, Pennycook, Bear, Rand \& Cannon, 2019).

One key factor in the belief and dissemination of misinformation appears to be partisanship. In one series of experiments, found that Democrats were more likely to believe the negative fake news stories featuring Republican politicians (both known and unknown), whereas Republicans were more likely to believe negative fake news featuring Democratic politicians (Pereira, Harris \& Van Bavel, 2020). This pattern existed across real news, actual fake news (from an online fake news source) and artificial fake news (stimuli created for the purpose of the experiment). A similar pattern of results was observed in partisan's willingness to share the fake news stories on social media. Along the same vein, when shown images of Obama's and Trump's inauguration crowds, Republicans were more likely to falsely believe that the image of Obama's crowd, which was objectively larger, was Trump's crowd as compared to Democrats (Schaffner \& Luks, 2018). As such, partisanship can impede our ability to discern fake from true news and might motivate people to spread the news with their social network.

Conspiracy Theories. Partisanship is also linked to the belief in conspiracy theories, particularly those that directly respond to goals related to partisan identity (e.g., Duran, Nicholson, \& Dale, 2017; Edelson, Alduncin, Krewson, Sieja, \& Uscinski, 2017; Enders \& Smallpage, 2018; Enders \& Smallpage, 2019; Miller, Saunders, \& Farhart, 2015; Pasek, Stark, Krosnick, \& Tompson, 2015; Smallpage, Enders \& Uscinski, 2017; see Chapter 34). For instance, one study found that people believed more strongly in conspiracy theories that implied a political outgroup was conspiring against them than groups without any political affiliation (e.g., Freemasons) (Smallpage, Enders \& Uscinski, 2017). Similarly, Republicans (vs. Democrats) were more likely to believe that Barack Obama was born outside of the United States, whereas the reverse pattern occurred for the idea that the Bush administration breached the flood levees in New Orleans during Hurricane Katrina (Enders, Smallpage \& Lupton, 2018). Such conspiracy theories are grounded in social identity needs and can be dangerous if they motivate people to engage in violence to defend themselves (see Sternisko, Cichocka, \& Van Bavel, 2020). 
While there seem to be ideological asymmetries in conspiracy theory beliefs (Van Der Linden, Panagopoulos, Azevedo, \& Jost, 2020), there is evidence that partisan differences may primarily stem from social identity motives on both sides of the political spectrum, similar to that of general beliefs and fake news belief. In one study, researchers presented people with a conspiracy theory and varied whether it implicated the Obama or the Bush administration. They found that participants who identified as Republican were more likely to believe the conspiracy theory when it implied the Obama (vs. Bush) administration as conspiring, whereas the reverse pattern occurred for participants who identified as Democrats (Enders \& Smallpage, 2018). Further, a study conducted in Pakistan found that citizens were more likely to believe conspiracy theories when they were allegedly endorsed by the party they supported (Siddiqui, 2020). Exposure to partisan conspiracy theories often activates competing implicit motives - accuracy motive and social motives - simultaneously (Duran, Nicholson, \& Dale, 2017). Depending on which motive takes priority, people come to different conclusions about the conspiracy theory. In other words, conspiracy theory beliefs emerge when social identity motives take priority over accuracy motives.

Partisan differences in conspiracy theory beliefs and distrust of the government shift based on which party holds power (see Morisi, Jost, \& Singh, 2019; Uscinski \& Parent, 2014). For example, party identification did not predict people's anticipation of voter fraud before the 2012 US Presidential elections. However, after the election (won by Democrat Barack Obama), Republicans were more likely to believe that voter fraud had occurred (Edelson, Alduncin, Krewson, Sieja \& Uscinski, 2017). Likewise, after the 2016 US presidential elections (won by Republican Donald Trump), beliefs in conspiracy theories, such as the idea that the US was run by a shadow government, increased amongst Democrats, but decreased amongst Republicans (Miller, Saunders \& Farhart, 2017). Similarly, during the 2004 Taiwanese Presidential elections, conspiracy theories about the attacks on the candidate of the Democratic Progressive Party were very popular amongst party sympathizers before, but less so after, the party's electoral victory was announced (Nefes, 2014). Adopting conspiracy theories may therefore help to maintain a positive image of one's political ingroup when externally challenged.

The relationship between partisanship and conspiracy theory beliefs has serious consequences for society (see Sternisko, Cichocka, \& Van Bavel, 2020). For instance, entertaining political conspiracy theories increased participants' willingness to take violent political action (Imhoff, Dieterle, \& Lamberty, 2020). Further, conspiracy theories are linked to political polarization. Correlational data from the Europe and the U.S. links belief in conspiracy theories to political extremism and radicalization (Bartlett \& Miller, 2010; Krouwel, Kutiyski, van Prooijen, Martinsson, \& Markstedt, 2017; van der Linden et al., 2020; van Prooijen, Krouwel, \& Pollet, 2015). A recent real-world example may be the conspiracy theory that the COVID-19 pandemic was exaggerated or fabricated by Democrats to politically hurt the Trump administration. This theory gathered popularity amongst high-ranking Republicans and conservative media outlets (Hawkins, 2020), threatening to seriously impede the containment of the disease. It is therefore not surprising that Republicans are more likely to hold such conspiracy theories about the pandemic (Sternisko, Cichocka, Cislak, \& Van Bavel, 2020). Partisanship can be a key facilitator of dangerous conspiracy theory beliefs.

\section{Voting Behavior}

Voting in government elections is inextricably influenced by both political belief and partisan identity. In the U.S., voter turnout is one of the lowest of all OECD countries; those who do vote are more likely to be partisans (Desilver, 2017; Johnston, 2006). However, many of the 
factors that influence an individual's decision to vote (i.e. moral convictions, negative partisanship, identity concerns) do not match political ideology (Mayer, 2017; Skitka \& Bauman 2005). Rather, the strength of partisan identity and party identification on either side of the ideological spectrum seems to have the most influence on voting behavior. Strength of party identification predicts intentions to vote for both liberals and conservatives over their more moderate party-mates (Greene, 1999; Morgan, Skitka, \& Wisneski, 2010). Those who do vote in elections tend to have greater polarization of their political identities, and those who hold moderate views on politics are the least likely to vote (Bartels, 2000). Individuals are far more likely to vote with their party and their partisan identity, and this party loyalty has been increasing since the 1970's.

While voting in elections appears to be one of the strongest and most important methods of voicing political support, voting in government elections makes little pragmatic sense rationally speaking, as the statistical probability of a single person's ballot making a meaningful difference in an election result is vanishingly small (Downs, 1957). In fact, when the irrationality of voting was made salient to people, they were less likely to actually vote on Election Day when compared to control groups (Blais \& Young 1999). Therefore, people who do get out and vote are likely motivated by non-pragmatic concerns, such as identity validation or expression. In support of this idea, one study incentivized people to accurately answer questions that either validated or threatened their partisan identity (Robbett \& Matthews, 2018). Depending on the condition, however, people either had to give their responses as individuals, or they were asked to "vote" on an answer with other participants, in groups of 5 or 25 . When a question threatened participants' partisan identities, those who answered individually were able to get the right answer, but those whose answers were aggregated answered incorrectly, choosing instead to cast their vote for the answer that aligned with their ideological beliefs. In other words, this type of "expressive voting" suggests that people's accuracy goals were outweighed by their identity goals, and this occurred most strongly when voting on an answer with others rather than answering as an individual. Taken together, these findings illuminate a possible mechanism for why those with stronger partisan identities are more likely to vote. Specifically, participating in general elections may serve less as an expression of actual desires and instead as a proxy for identity signaling and expressive voting.

\section{Conclusion}

A burgeoning literature suggests that partisanship is a form of social identity with interesting and wide-reaching implications for our brains and behavior. In some ways, the effects of partisanship mirror those of other forms of group identity, both behaviorally and in the brain. However, partisanship also has interesting biological antecedents and effects in political domains such as belief in fake news and conspiracy theories, as well as voting behavior. As political polarization rises in many nations across the world, partisanship will become an increasingly divisive and influential form of social identity in those countries, thus highlighting the urgency to understand its psychological and neural underpinnings. 


\section{References}

Anduiza, E., Gallego, A., \& Muñoz, J. (2013). Turning a Blind Eye: Experimental Evidence of Partisan Bias in Attitudes Toward Corruption. Comparative Political Studies, 46(12), 1664-1692.

Anwar, S., Bayer, P., \& Hjalmarsson, R. (2012). The Impact of Jury Race in Criminal Trials. The Quarterly Journal of Economics, 127(2), 1017-1055.

Barberá, P. (2015). Birds of the Same Feather Tweet Together: Bayesian Ideal Point Estimation Using Twitter Data. Political analysis, 23(1), 76-91.

Baron, J., \& Jost, J. T. (2019). False Equivalence: Are Liberals and Conservatives in The United States Equally Biased?. Perspectives on Psychological Science, 14(2), 292-303.

Bartels, L. M. (2002). Beyond the Running Tally: Partisan Bias in Political Perceptions. Political behavior, 24(2), 117-150.

Bartels, L. M. (2000). Partisanship and Voting Behavior, 1952-1996. American Journal of Political Science, 35-50.

Bartlett, J., \& Miller, C. (2010). The Power of Unreason: Conspiracy Theories, Extremism and Counter-terrorism. London: Demos.

Bartra, O., McGuire, J. T., \& Kable, J. W. (2013). The Valuation System: A Coordinate-based Meta-analysis of BOLD fMRI Experiments Examining Neural Correlates of Subjective Value. Neuroimage, 76, 412-427.

Blais, A., \& Young, R. (1999). Why Do People Vote? An Experiment in Rationality. Public Choice, 99(1-2), 39-55.

Boxell, L., Gentzkow, M., \& Shapiro, J. M. (2020). Cross-country Trends in Affective Polarization (No. w26669). National Bureau of Economic Research. Available from 
https://www.nber.org/papers/w26669.

Brewer, M. B. (1999). The Psychology of Prejudice: Ingroup Love and Outgroup Hate?. Journal of social issues, 55(3), 429-444.

Brewer, M. B. (1979). In-group Bias in the Minimal Intergroup Situation: A CognitiveMotivational Analysis. Psychological bulletin, 86(2), 307.

Bronstein, M. V., Pennycook, G., Bear, A., Rand, D. G., \& Cannon, T. D. (2019). Belief in Fake News is Associated With Delusionality, Dogmatism, Religious Fundamentalism, and Reduced Analytic Thinking. Journal of Applied Research in Memory and Cognition, $8(1), 108-117$.

Brown, A. (2020, April 24). Most Democrats Who Are Looking for a Relationship Would Not Consider Dating a Trump Voter. Pew Research Center. Retrieved from https://www.pewresearch.org/fact-tank/2020/04/24/most-democrats-who-are-looking-fora-relationship-would-not-consider-dating-a-trump-voter/

Bullock, J. G., Gerber, A. S., Hill, S. J., \& Huber, G. A. (2015). Partisan Bias in Factual Beliefs About Politics. Quarterly Journal of Political Science, 10(4), 519-578.

Bullock, J. G. (2009). Partisan Bias and the Bayesian Ideal in the Study of Public Opinion. The Journal of Politics, 71(3), 1109-1124.

Bullock, J. (2007). Experiments on Partisanship and Public Opinion: Party Cues, False Beliefs, and Bayesian Updating. Ph.D. dissertation, Stanford University

Carlson, E. (2016). Finding Partisanship Where We Least Expect it: Evidence of partisan bias in a new African democracy. Political Behavior, 38(1), 129-154.

Carlson, E. (2015). Ethnic Voting and Accountability in Africa: A Choice Experiment in Uganda. HeinOnline. 
Chawke, C., \& Kanai, R. (2016). Alteration of political belief by non-invasive brain stimulation. Frontiers in human neuroscience, 9, 621.

Che, Y. K., \& Mierendorff, K. (2019). Optimal Dynamic Allocation of Attention. American Economic Review, 109(8), 2993-3029.

Chen, Y., \& Li, S. X. (2009). Group Identity and Social Preferences. American Economic Review, 99(1), 431-57.

Cikara, M., Van Bavel, J. J., Ingbretsen, Z. A., \& Lau, T. (2017). Decoding “Us” and "Them”: Neural Representations of Generalized Group Concepts. Journal of Experimental Psychology: General, 146(5), 621.

Cohen, G. L. (2003). Party over Policy: The Dominating Impact of Group Influence on Political Beliefs. Journal of personality and social psychology, 85(5), 808.

Coppock, A. E. (2016). Positive, Small, Homogeneous, and Durable: Political Persuasion in Response to Information (Doctoral dissertation, Columbia University).

Craig, M. A., \& Richeson, J. A. (2014). On the Precipice of a "Majority-minority" America: Perceived Status Threat from the Racial Demographic Shift Affects White Americans' Political Ideology. Psychological science, 25(6), 1189-1197.

Cross, W., \& Young, L. (2002). Policy Attitudes of Party Members in Canada: Evidence of Ideological Politics. Canadian Journal of Political Science/Revue canadienne de science politique, 859-880.

Dayan, P., \& Solomon, J. A. (2010). Selective Bayes: Attentional Load and Crowding. Vision research, 50(22), 2248-2260.

DeSilver, D. (2017). US Trails Most Developed Countries in Voter Turnout. Pew Research Center, 15. 
Desilver, D. (2013). Partisan Polarization, in Congress and Among Public, is Greater Than Ever. Pew Research Center.

Ditto, P. H., Liu, B. S., Clark, C. J., Wojcik, S. P., Chen, E. E., Grady, R. H., Celniker, J. B., \& Zinger, J. F. (2019). At Least Bias Is Bipartisan: A Meta-Analytic Comparison of Partisan Bias in Liberals and Conservatives. Perspectives on Psychological Science, 14(2), 273-291.

Downs, A. (1957). An Economic Theory of Democracy.

Duran, N. D., Nicholson, S. P., \& Dale, R. (2017). The Hidden Appeal and Aversion to Political Conspiracies as Revealed in the Response Dynamics of Partisans. Journal of Experimental Social Psychology, 73, 268-278.

Edelson, J., Alduncin, A., Krewson, C., Sieja, J. A., \& Uscinski, J. E. (2017). The Effect of Conspiratorial Thinking and Motivated Reasoning on Belief in Election Fraud. Political Research Quarterly, 70(4), 933-946.

Enders, A. M., \& Smallpage, S. M. (2018). On the Measurement of Conspiracy Beliefs. Research \& Politics. 5:1-4

Enders, A. M., Smallpage, S. M., \& Lupton, R. N. (2018). Are All 'Birthers' Conspiracy Theorists? On the Relationship Between Conspiratorial Thinking and Political Orientations. British Journal of Political Science, 1-18.

Fazio, L. K., Rand, D. G., \& Pennycook, G. (2019). Repetition Increases Perceived Truth Equally for Plausible and Implausible Statements. Psychonomic bulletin \& review, 26(5), 1705-1710.

Festinger, L., Riecken, H.W., Schachter, S. (1956). When Prophecy Fails. Mineapolis : University of Minesota Press. 
Frimer, J. A., Skitka, L. J., \& Motyl, M. (2017). Liberals and Conservatives are Similarly Motivated to Avoid Exposure to One Another's Opinions. Journal of Experimental Social Psychology, 72, 1-12.

Gerber, A. S., \& Huber, G. A. (2010). Partisanship, Political Control, and Economic Assessments. American Journal of Political Science, 54(1), 153-173.

Gerber, A., \& Green, D. P. (1998). Rational Learning and Partisan Attitudes. American journal of political science, 794-818.

Goette, L., Huffman, D., \& Meier, S. (2012). The Impact of Social Ties on Group Interactions: Evidence From Minimal Groups and Randomly Assigned Real Groups. American Economic Journal: Microeconomics, 4(1), 101-15.

Gollwitzer, A., Martel, C., Brady, W. J., Pärnamets, P., Freedman, I., Knowles, E., \& Van Bavel, J. J. (2020, May 24). Partisan Differences in Physical Distancing Predict Infections and Mortality During the Coronavirus Pandemic.

Gottlieb, J. (2018). Understanding Active Sampling Strategies: Empirical Approaches and Implications for Attention and Decision Research. Cortex, 102, 150-160.

Graf, J., \& Aday, S. (2008). Selective Attention to Online Political Information. Journal of Broadcasting \& Electronic Media, 52(1), 86-100.

Graham, J., Haidt, J., \& Nosek, B. A. (2009). Liberals and Conservatives Rely on Different Sets of Moral Foundations. Journal of personality and social psychology, 96(5), 1029.

Greene, S. (2002). The Social-psychological Measurement of Partisanship. Political Behavior, 24(3), 171-197.

Greene, S. (1999). Understanding Party Identification: A Social Identity Approach. Political Psychology, 20(2), 393-403. 
Harris, E., \& Van Bavel, J. J.(in press). Preregistered Replication of "Feeling Superior is a Bipartisan Issue: Extremity (Not Direction) of Political Views Predicts Perceived Belief Superiority". Psychological Science.

Hartman, T. K., \& Newmark, A. J. (2012). Motivated Reasoning, Political Sophistication, and Associations Between President Obama and Islam. PS: Political Science \& Politics, 45(3), 449-455.

Hartstone, M., \& Augoustinos, M. (1995). The Minimal Group Paradigm: Categorization Into Two Versus Three Groups. European Journal of Social Psychology, 25(2), 179-193.

Hatemi, P. K., Medland, S. E., Klemmensen, R., Oskarsson, S., Littvay, L., Dawes, C. T., Verhulst, B., McDermott, R., Nørgaard, A. S., Klofstad, C. A., Christensen, K., Johannesson, M., Magnusson, P. K., Eaves, L. J., \& Martin, N. G. (2014). Genetic Influences on Political Ideologies: Twin Analyses of 19 Measures of Political Ideologies From Five Democracies and Genome-wide Findings from Three Populations. Behavior Genetics, 44(3), 282-294.

Hawkins, D. (2020, May 17). Eric Trump claims coronavirus is Democratic hoax, will ‘magically' vanish after 2020 election. Washington Post. https://www.washingtonpost.com/politics/2020/05/17/eric-trump-coronavirus/

Mercier, H., \& Sperber, D. (2011). Why Do Humans reason? Arguments for an Argumentative Theory.

Hibbing, J. R., Smith, K. B., \& Alford, J. R. (2013). Predisposed: Liberals, Conservatives, and the Biology of Political Differences. Routledge.

Mitchell, J. P., Macrae, C. N., \& Banaji, M. R. (2006). Dissociable Medial Prefrontal Contributions to Judgments of Similar and Sissimilar Others. Neuron, 50(4), 655-663. 
Hornsby, A. N., \& Love, B. C. (2020). How Decisions and the Desire for Coherency Shape Subjective Preferences over Time. Cognition, 200, 104244.

Huddy, L. (2001). From Social to Political Identity: A Critical Examination of Social Identity Theory. Political psychology, 22(1), 127-156.

Hunt, J. (2017, November). 'Fake news' named Collins Dictionary's official Word of the Year for 2017. The Independent. Retrieved from https://www.independent.co.uk/news/uk/homenews/fake-news-word-of-the-year-2017-collins-dictionary-donald-trump-kellyanneconway-antifa-corbynmania-a8032751.html

Imhoff, R., Dieterle, L., \& Lamberty, P. (2020). Resolving the Puzzle of Conspiracy Worldview and Political Activism: Belief in Secret Plots Decreases Normative but Increases Nonnormative Political Engagement. Social Psychological and Personality Science.

Iyengar, S., \& Krupenkin, M. (2018). The Strengthening of Partisan Affect. Political Psychology, 39, 201-218.

Iyengar, S., Lelkes, Y., Levendusky, M., Malhotra, N., \& Westwood, S. J. (2019). The Origins and Con-sequences of Affective Polarization in the United States. Annual Review of Political Science, 22, 129-146.

Johnston, R. (2006). Party Identification: Unmoved Mover or Sum of Preferences?. Annual Review of Political Science., 9, 329-351.

Jost, J. T., Glaser, J., Kruglanski, A. W., \& Sulloway, F. J. (2003). Political Conservatism as Motivated Social Cognition. Psychological bulletin, 129(3), 339.

Jost, J. T., Hennes, E. P., \& Lavine, H. (2013). "Hot” Political Cognition: Its Self-, Group-, and System-serving Purposes. Oxford handbook of social cognition, 851, 875.

Jost, J. T., Noorbaloochi, S., \& Van Bavel, J. J. (2014). The" chicken-and-egg" problem in 
political neuroscience. Behavioral and Brain Sciences, 37(3), 317.

Jurkowitz, M., Mitchell, A., Shearer, E., \& Walker, M. (2020). US Media Polarization and the 2020 Election: A Nation Divided. Pew Research Center.

Kahan, D. M., Peters, E., Dawson, E. C., \& Slovic, P. (2017). Motivated numeracy and enlightened self-government. Behavioural Public Policy, 1(1), 54-86.

Kelley, W. M., Macrae, C. N., Wyland, C. L., Caglar, S., Inati, S., \& Heatherton, T. F. (2002). Finding the self? An event-related fMRI study. Journal of cognitive neuroscience, 14(5), 785-794.

Kevins, A., \& Soroka, S. N. (2018). Growing apart? Partisan sorting in Canada, 1992-2015.

Canadian Journal of Political Science/Revue canadienne de science politique, 51(1), 103-133.

Klein, E. (2020). Why we're polarized. Profile Books.

Knutson, K. M., Wood, J. N., Spampinato, M. V., \& Grafman, J. (2006). Politics on the brain: An fMRI investigation. Social Neuroscience, , 1(1), 25-40.

Kozlowski, A., \& Murphy, J. P. (2019). Issue Alignment and Partisanship in the American Public: Revisiting the 'Partisans without Constraint' Thesis. PsyArXiv.

Krouwel, A., Kutiyski, Y., van Prooijen, J.-W., Martinsson, J., \& Markstedt, E. (2017). Does Extreme Political Ideology Predict Conspiracy Beliefs, Economic Evaluations and Political Trust? Evidence from Sweden. Journal of Social and Political Psychology, 5(2), 435-462.

Kunda, Z. (1990). The Case for Motivated Reasoning. Psychological bulletin, 108(3), 480.

Lelkes, Y., \& Westwood, S. J. (2017). The Limits of Partisan Prejudice. The Journal of Politics, 79(2), 485-501.

Lewis, G. J., Bates, T. C. (2010) Genetic Evidence for Multiple Biological Mechanisms 
Underlying In-group Favoritism. Psychological Science, 21, 1623-1628.

Lewis, G. J., Kandler, C., \& Riemann, R. (2014). Distinct Heritable Influences Underpin InGroup Love and Out-Group Derogation. Social Psychological and Personality Science, 5(4), 407-413.

Lupu, N. (2015). Party Polarization and Mass Partisanship: A Comparative Perspective. Political Behavior, 37(2), 331-356.

Mason, L. (2018). Uncivil Agreement: How Politics Became Our Identity.

Mayer, S. J. (2017). How Negative Partisanship Affects Voting Behavior in Europe: Evidence From an Analysis of 17 European Multi-party Systems With Proportional Voting. Research \& Politics, 4(1)

McConnell, C., Margalit, Y., Malhotra, N., \& Levendusky, M. (2018). The Economic Consequences of Partisanship in a Polarized Era. American Journal of Political Science, $62(1), 5-18$.

McGuire, W. (1964). : Inducing Resistance to Persuasion, in L. Berkowitz (ed.): Advances in Experimental Social Psychology.

McNamara, J., \& Houston, A. (1980). The Application of Statistical Decision Theory to Animal Behaviour. Journal of Theoretical Biology, 85(4), 673-690.

Meffert, M. F., Chung, S., Joiner, A. J., Waks, L., \& Garst, J. (2006). The Effects of Negativity and Motivated Information Processing During a Political Campaign. Journal of Communication, 56(1), 27-51.

Miller, J. M., Saunders, K. L., \& Farhart, C. E. (2016). Conspiracy Endorsement as Motivated Reasoning: The Moderating Roles of Political Knowledge and Trust. American Journal of Political Science, 60(4), 824-844. 
Morisi, D., Jost, J. T., \& Singh, V. (2019). An Asymmetrical "President-in-power" Effect. American Political Science Review, 113(2), 614-620.

Morgan, G. S., Skitka, L. J., \& Wisneski, D. C. (2010). Moral and Religious Convictions and Intentions to Vote in the 2008 Presidential Election. Analyses of Social Issues and Public Policy (ASAP), 10(1), 307-320

Nam, H. H., Jost, J. T., Kaggen, L., Campbell-Meiklejohn, D., \& Van Bavel, J. J. (2018). Amygdala structure and the tendency to regard the social system as legitimate and desirable. Nature Human Behaviour, 2(2), 133-138.

Nefes, T. S. (2014). Rationale of Conspiracy Theorizing: Who Shot the President Chen Shuibian?. Rationality and Society, 26(3), 373-394.

Nyhan, B. (2017). Why More Democrats are Now Embracing Conspiracy Theories. Retrieved from https://www.nytimes. com/2017/02/15/upshot/why-more-democrats-are-nowembracing-conspiracy-theories.html

Nyhan, B., \& Reifler, J. (2010). When Corrections Fail: The Persistence of Political Misperceptions. Political Behavior, 32(2), 303-330.

Pasek, J., Stark, T. H., Krosnick, J. A., \& Tompson, T. (2015). What Motivates a Conspiracy Theory? Birther Beliefs, Partisanship, Liberal-conservative Ideology, and Anti-Black Attitudes. Electoral Studies, 40, 482-489.

Pereira, A., Harris, E., \& Van Bavel, J. J. (under review). Identity Concerns Drive Belief: The Impact of Partisan Identity on the Belief and Dissemination of True and False News.

Pew Research Center. (2020). In Changing U.S. Electorate, Race and Education Remain Stark Dividing Lines. Retrieved from https://www.people-press.org/2020/06/02/in-changing-us-electorate-race-and-education-remain-stark-dividing-lines/ 
Pew Research Center. (2017). The Partisan Divide on Political Values Grows Even Wider. Retrieved from http://www.people-press.org/2017/10/05/the-partisan-divide-on-politicalvalues-grows-even-wider/

Pew Research Center. (2014). Political Polarization in the American Public. Retrieved from www.people-press.org/2014/06/12/political-polarization-in-the-american-public/ Ripberger, J. T., Jenkins-Smith, H. C., Silva, C. L., Carlson, D. E., Gupta, K., Carlson, N., \& Dunlap, R. E. (2017). Bayesian Versus Politically Motivated Reasoning in Human Perception of Climate Anomalies. Environmental Research Letters, 12(11), 114004.

Robbett, A., \& Matthews, P. H. (2018). Partisan Bias and Expressive Voting. Journal of Public Economics, 157, 107-120.

Rollwage, M., Dolan, R. J., \& Fleming, S. M. (2018). Metacognitive Failure as a Feature of Those Holding Radical Beliefs. Current Biology, 28(24), 4014-4021.

Ross, L., Lepper, M. R., \& Hubbard, M. (1975). Perseverance in Self-perception and Social Perception: Biased Attributional Processes in the Debriefing Paradigm. Journal of personality and social psychology, 32(5), 880.

Samuels, D., \& Zucco Jr, C. (2014). The Power of Partisanship in Brazil: Evidence From Survey Experiments. American Journal of Political Science, 58(1), 212-225.

Sarlin, B. (2018, January). 'Fake news' Went Viral in 2016. This Expert Studied Who Clicked. NBC News. Retrieved from https://www.nbcnews.com/politics/politics-news/fake-newswent-viral-2016-expert-studied-who-clicked-n836581

Schaffner, B. F., \& Luks, S. (2018). Misinformation or Expressive Responding? What an Inauguration Crowd Can Tell Us About the Source of Political Misinformation in Surveys. Public Opinion Quarterly, 82(1), 135-147. 
Shafranek, R. M. (2019). Political Considerations in Nonpolitical Decisions: A Conjoint Analysis of Roommate Choice. Political Behavior, 1-30.

Shearer, E., \& Gottfried, J. (2017). News Use Across Social Media Platforms 2017. Pew Research Center.

Sherif, M. (1954). Status in Experimentally Produced Groups. American Journal of Sociology

Shook, N. J., \& Fazio, R. H. (2009). Political Ideology, Exploration of Novel Stimuli, and Attitude Formation. Journal of Experimental Social Psychology, 45(4), 995-998.

Siddiqui, N. (2020). Who Do you Believe? Political Parties and Conspiracy Theories in Pakistan. Party Politics, 26(2), 107-119.

Silverman, C. (2016). This Analysis Shows How Viral Fake Election News Stories Outperformed Real News on Facebook. BuzzFeed News, 16.

Skitka, L. J., Bauman, C. W., \& Sargis, E. G. (2005). Moral Conviction: Another Contributor to Attitude Strength or Something More? Journal of Personality and Social Psychology, 88(6), 895-917.

Smallpage, S. M., Enders, A. M., \& Uscinski, J. E. (2017). The Partisan Contours of Conspiracy Theory Beliefs. Research \& Politics, 4(4).

Smith, J. (2010). Minimal group effect. In J. M. Levine \& M. A. Hogg (Eds.), Encyclopedia of group processes \& intergroup relations (pp. 555-557). Thousand Oaks, CA: SAGE Publications, Inc. doi: 10.4135/9781412972017.n169

Stern, C., West, T. V., \& Schmitt, P. G. (2014). The Liberal Illusion of Uniqueness. Psychological Science, 25(1), 137-144.

Sternisko, A., Cichocka, A., \& Van Bavel, J. J. (2020). The Dark Side of Social Movements: 
Social Identity, Non-conformity, and the Lure of Conspiracy Theories. Current Opinion in Psychology, 35, 1-6.

Strandberg, T., Olson, J. A., Hall, L., Woods, A., \& Johansson, P. (2020). Depolarizing American Voters: Democrats and Republicans are Equally Susceptible to False Attitude Feedback. Plos one, 15(2), e0226799.

Strandberg, T., Sivén, D., Hall, L., Johansson, P., \& Pärnamets, P. (2018). False Beliefs and Confabulation Can Lead to Lasting Changes in Political Attitudes. Journal of Experimental Psychology: General, 147(9), 1382.

Taber, C. S., \& Lodge, M. (2006). Motivated Skepticism in the Evaluation of Political Beliefs. American journal of political science, 50(3), 755-769.

Taber, C. S., Lodge, M., \& Glathar, J. (2001). The Motivated Construction of Political Judgments. In J. H. Kuklinski (Ed.), Cambridge studies in political psychology and public opinion. Citizens and politics: Perspectives from political psychology (p. 198226). Cambridge University Press.

Tajfel, H. (1970). Experiments in Intergroup Discrimination. Scientific American, 223(5), 96103.

Tappin M. B., Pennycook G., Rand D., R. (2020) Thinking Clearly About Casual Inferences of Politically Motivated Reasoning: Why Paradigmatic Study Designs Often Undermine Casual Inference. 34: 81-87

Tajfel, H., Billig, M.G., Bundy, R.P. and Flament, C. (1971), Social Categorization and Intergroup Behaviour. Eur. J. Soc. Psychol., 1: 149-178

Tetlock, Philip E. (1985). Accountability: A Social Check on the Fundamental Attribution Error. Social Psychology Quarterly 48: 227-238. 
Toner, K., Leary, M. R., Asher, M. W., \& Jongman-Sereno, K. P. (2013). Feeling Superior is a Bipartisan Issue: Extremity (not direction) of Political Views Predicts Perceived Belief Superiority. Psychological Science, 24(12), 2454-2462.

Tucker, J. A., Guess, A., Barberá, P., Vaccari, C., Siegel, A., Sanovich, S., ... \& Nyhan, B. (2018). Social Media, Political Polarization, and Political Disinformation: A Review of the Scientific Literature. Political polarization, and political disinformation: a review of the scientific literature (March 19, 2018).

Uscinski, J. E., \& Parent, J. M. (2014). American conspiracy theories. Oxford University Press. Van Bavel, J. J., Packer, D. J., \& Cunningham, W. A. (2008). The neural substrates of ingroup bias: a functional magnetic resonance imaging investigation. Psychological science, 19(11), 1131-1139.

Van Bavel, J. J., Packer, D. J., \& Cunningham, W. A. (2008). The Neural Substrates of In-Group Bias: A Functional Magnetic Resonance Imaging Investigation. Psychological Science, 19(11), 1131-1139. https://doi.org/10.1111/j.1467-9280.2008.02214.x

Van Bavel, J.J. \& Pereira, A. (2018). The Partisan Brain: An Identity-based Model of Political Belief. Trends in Cognitive Sciences, 22, 213-224

Van Bavel, J. J., Sternisko, A., Harris, E., \& Robertson, C. (2020). The social function of rationalization: An identity perspective. Behavioral and Brain Sciences, 43.

Van der Linden, S., Panagopoulos, C., Azevedo, F., \& Jost, J. J. (2020) The Paranoid Style in American Politics Revisited: An Ideological Asymmetry in Conspiratorial Thinking. Political Psychology.

Verhulst, B., Eaves, L.J. and Hatemi, P.K. (2012), Correlation not Causation: The Relationship 
between Personality Traits and Political Ideologies. American Journal of Political Science, 56: 34-51.

Vosoughi, S., Roy, D., \& Aral, S. (2018). The Spread of True and False News Online. Science, 359(6380), 1146-1151.

Xiao, Y. J. \& Van Bavel, J.J. (2019). Sudden Shifts in Social Identity Swiftly Shape Implicit Evaluation. Journal of Experimental Social Psychology, 83, 55-69.

Yudkin, D. A., Rothmund, T., Twardawski, M., Thalla, N., \& Van Bavel, J. J. (2016). Reflexive Intergroup Bias in Third-party Punishment. Journal of experimental psychology: general, 145(11), 1448.

Zimerman, A., \& Pinheiro, F. (2020). Appearances Can Be Deceptive: Political Polarization, Agrarian Policy, and Coalitional Presidentialism in Brazil. Politics \& Policy, 48(2), 339371.

Zmigrod, L., Rentfrow, P. J., \& Robbins, T. W. (2019). The Partisan Mind: Is Extreme Political Partisanship Related to Cognitive Inflexibility?. Journal of Experimental Psychology: General.

Wilson, A., Parker, V., Feinberg, M. (2020) Polarization in the Contemporary Political and Media Landscape, Current Opinion in Behavioral Sciences, 34, 223-228 